\title{
Atopik Dermatit
}

\section{Özet}

Atopik dermatit sanayileșmiș toplumlarda önemli bir sağlık sorunu olarak karșımıza çıkarken, gelișmekte olan ülkemizde ise sıklığı giderek artıș göstermektedir. Bu derlemede, etyopatogenezi, klinik bulguları ve güncel tedavi yaklașımları son kılavuzlar ve literatür eșliğinde gözden geçirilerek aktarılmaktadır. (Türkderm 2011; 45: 168-73)

Anahtar Kelimeler: Atopik dermatit

\section{Summary}

Atopic dermatitis is one of the important public health problems of the industrialized communities, and the prevalence of the disease has been increasing in our developing country. In this paper, etiopathogenesis, clinical characteristics and current therapeutic approaches of atopic dermatitis is reviewed under highlights of recently published guidelines and the literature. (Turkderm 201 1; 45: 168-73) Key Words: Atopic dermatitis

\section{Giriş}

Atopik dermatit $(A D)$, kronik seyirli relaps ve remisyonlar ile seyreden, kaşıntılı bir deri hastalığıdır. Hastalık eski Yunancada yabancı (strange) ya da alışılmadık (unusual) anlamına gelen atopos kelimesinden köken almaktadır. 1892 yılında ilk defa Besnier atopik dermatitin, alerjik rinit ve astım ile birlikteliğini tanımlamıştır. Sonraki yıllarda bu birliktelik otörler tarafından da kabul görmüştür. 1930'lu yıllarda "atopik dermatit" terminolojisi kullanılmaya başlanmıştır. 1980'lerde Hanifin ve Rajka tarafından hastalığın majör ve minör bulguları tanımlanmıştır (Tablo1). 1994 yılında bir grup İngiliz araştırıcı epidemiyolojik çalışmalarda kullanılmak üzere bu bulguları tekrar düzenlemiştir (Tablo 2).$^{1-3}$

\section{Epidemiyoloji:}

Atopik dermatit, her yaşta görülebilmekle birlikte hastaların \%90'nında 5 yaşından önce, \%50'sinde infantil dönemde ikinci aydan sonra başlamaktadır. Çocukluk çağının en sık rastlanan kronik deri hastalığıdır. Hastalığının prevalansı ikinci dünya savaşından sonra giderek artmıştır. Sanayileşme, kentleşme ve iklim değişiklikleri hastalığın sıklığını etkilemektedir. Kuzeybatı Avrupa ülkelerinde, Amerika'da, Avustralya'da okul çağı çocukları arasında görülme oranı \%20-30 olarak bildirilmektedir. Akdeniz, Afrika ve Doğu Avrupa ülkelerinde daha az sıklıkta görülmektedir. ${ }^{1}$ Ülkemizde ise 6-13 yaş arası çocuklarda \%4,3 ${ }^{4}, 10-11$ yaş arası çocuklarda prevalansı \%8,1 olarak bulunmuştur. ${ }^{5}$ Hastalık anksiyete, depresyon gelişimine yol açmakta ve hastaların yaşam kalitesini olumsuz yönde etkilemektedir. ${ }^{6}$

Çalışmaların birçoğunda kızlarda erkeklere göre görülme oranı bir miktar daha fazla olarak bulunmuştur. Hastalık çevresel ve genetik faktörlerin etkileşimi sonucu gelişmektedir. Ebeveynlerden özellikle annedeki atopi öyküsü hastalık gelişimi için güçlü bir risk faktörüdür. ${ }^{1}$ Hastalığın görülme insidansı ebeveynlerden birinde atopi öyküsü varlığında iki katına, her iki ebeveynde hastalık öyküsü var ise üç katına çıkmaktadır.?

Hijyen teorisine göre, erken çocukluk çağında çeşitli alerjen ve infeksiyon ajanları ile karşılaşmayı sağlayan hijyenik olmayan ortamlarda regülatuvar T lenfositler aracılığıyla immün tolerans gelişmekte ve atopi görülme sıklığı azalmaktadır.

Yazışma Adresi/Address for Correspondence: Dr. Bengü Gerçeker Türk, Ege Üniversitesi Tıp Fakültesi, Deri ve Zührevi Hastalıklar Ana Bilim Dall, lzmir, Türkiye Tel.: +90 2323903831 E-posta: bengugerceker@yahoo.com Geliş Tarihi/Received: 10.11.2011 Kabul Tarihi/Accepted: 14.11.2011

Türkderm-Deri Hastalıkları ve Frengi Arșivi Dergisi, Galenos Yayınevi tarafından basılmıștır. Turkderm-Archives of the Turkish Dermatology and Venerology, published by Galenos Publishing. 
Atopik Dermatit tanısı esas olarak klinik bulguların varlığında diğer hastalıkların dışlanması ardından konulur. Bazı otörler lg E yüksekliği ve spesifik Ig E varlığı ile seyreden hastalığı ekstrinsik $A D$, Ig E ilişkili olmayan tabloyu ise intrinsik $A D$ ya da atopiform dermatitler olarak ayırmaktadır. Ancak bu ayrım tartışmalı olup aynı klinik tablonun farklı aşamaları olduğu da düşünülmektedir. ${ }^{3}$ Hastalık tanısında Hanifin ve Rajka tarafından ortaya konmuş kriterler kullanılmaktadır. Hastalık başlıca "Score in Atopic Dermatitis" (SCORAD) indeksine ya da "Eczema Area and Severity Index" (EASI) göre hafif, orta ve şiddetli olarak sınıflandırılmaktadır.1.3

\section{Tablo 1. Atopik dermatit tanı kriterleri (1)}

\section{Major Kriterler (En az üç major kriter bulunmalıdır)} Kaşıntı

Tipik morfolojik özellik ve dağıım gösteren deri lezyonları Kronik ya da kronik bir şekilde tekrarlayan dermatit Kişide ya da ailesinde atopi öyküsü

Minör Kriterler (En az üç minör kriter bulunmalıdır)

\section{Kuruluk}

iktiyoz, palmar hiperlinearite, keratozis pilaris

Erken (Tip I) deri testi reaktivitesi

Artmış serum lgE düzeyi

Erken başlangıç yaşı

Deri infeksiyonlarına eğilim/Hücresel immunitede zayıflık

Nonspesifik el ve atak dermatitlerine yatkınlık

Meme başı ekzeması

Keilitis

Rekürren konjonktivit

Dennie-Morgan çizgileri

Keratokonus

Anterior subkapsüler katarakt

Göz çevresinde morluk

Fasiyal eritem

Pitriasis alba

Boyun anteriorunda deri katlantısı

Terleme ile tetiklenen kaşıntı

Deterjan ve yağ çözücülere intolerans

Perifolliküler belirginlik

Gıda intoleransı

Çevresel ya da emosyonel faktörler tarafından etkilenen klinik seyir Beyaz dermografizm

Tablo 2. Epidemiyolojkk çalışmalar için önerilen tanı kriterleri (1)

\section{Olmazsa olmaz;}

*Son iki ayda yaşanan kaşıntılı deri hastalı̆ı̆ ( ebeveyn tarafından belirtilen kaşıntı/sürtme/ovalama bildirilmesi)

Ek olarak aşağıdakilerden 3 ya da daha fazlası bulunmalıdır;

**El bileği, diz çukurları, dirsek ön yüzleri, boyun çevresi gibi deri katlantı bölgelerinin tutulumu

(10 yaşın altındaki çocuklarda ek olarak yanak bölgeleri)

*Özgeçmişte astma ya da saman nezlesi ( 4 yaşından küçük çocuklar için 1. derece akrabada atopik hastalık)

*Son bir yıl içerisinde genel olarak kuru deri öyküsü

*Belirgin fleksural ekzema (4 yaşından küçük çocuklarda yanak, alın ve ekstremitelerin ekstensör yüzlerinde ekzema)

*2 yaşın altında başlangıç (Bu kriter çocuk 4 yaşından küçük ise kullanılmaz)

\section{Patogenez:}

\section{Genetik faktörler:}

Hastaların yaklaşı \% 70 'inde aile öyküsü olması atopinin genetik olarak kalıtılığını düşündürmektedir. AD olgularının ailelerinde solunum alerjisinin de eşlik ettiği AD görülme oranı \%34, solunum alerjisi olmadan AD görülme oranı \%27 olarak saptanmıştır. İkiz çalışmaları AD'nin monozigotik ikizlerde dizigotik ikizlere göre daha sık geliştiğini ortaya koymuştur. Bu nedenle AD ilişkili genler araştırılmıştır. Kromozom 5q31-33, T hepler (Th) 2 sitokinlerden IL-3, IL-4, IL-5, IL-13 ve granulosit makrofaj koloni sitimulan faktör (GMKSF) ile ilişkili genleri içerir. ${ }^{1,3,6}$

Kromozom bölgelerinden $3 q 21$ 'in ve 5q31'in artmış serum IgE ve atopi ile ilişkisi bulunmuştur. Bu lokustaki genler T hücre aktivasyonu ve Th2 sitokinlerin ekspresyonunda görevli molekülleri kodlamaktadır. Yüksek affiniteli lgE reseptörünü (FcعRl; 11q13), mast hücre kimaz (14q11), IL4RA (İnterlökin 4 reseptör alfa zinciri, SPINK5 (serine proteaz inhibitör, Kazal tip 5), Toll benzeri reseptör 2 polimorfizmleri AD ile ilişkili bulunmuş mutasyonlardır.

Hastalığın gelişiminde filagrin mutasyonlarının çevresel faktörlerden etkilenen değişen ekspresyonları rol oynar. Kromozom 1q21'de yerleşen epidermal differensiyasyonu düzenleyen kompleks içerisinde yer alan FLG keratinositlerdeki keratin agregasyonunu düzenleyen proteinleri kodlamaktadır.7 Homozigotlarda yüksek penetrans, heterozigotlarda ise azalan bir penetrans göstermektedir. Aynı gen iktiyozis vulgariste de etkilenmektedir. Bu nedenle iktiyozis vulgarisli olgularda \%50'ye varan oranlarda ek olarak AD görülmektedir. AD'li Avrupalı çocuklarda filagrin varyantlarının \%20-50 arasında saptandığı, orta ve şiddetli seyreden hastalık varlığında ise bu oranın \%50 üzerinde olduğu, kontrol grubunda ise \%10 altında görüldüğü bildirilmiştir., 9

\section{Immunolojik mekanizmalar:}

$A D$ olgularında en sık saptanan alerjenler; ev tozları, polenler, hayvan kepeği ve küf mantarlarıdır. Gıda alerjileri bebek ve çocuk hastalarda özellikle inek sütü proteinlerine, yumurtaya, kabuklu fındık, fıstık gibi kuruyemişlere, soya ve buğdaya karşı gelişir. Özellikle orta ve şiddetli AD seyrinde gıda alerjisi \%40 varan oranlarda saptanabilmektedir. İrritan maddeler ve protein yapıdaki alerjenlere karşı hastaların hassasiyeti artmıştır. Ekzojen alerjenlere karşı gelişen alerjik yanıt deride endojen proteinlere karşı otoalerji gelişmesine de yol açabilmektedir. Hastalarda IgE aracılı sistemik bulgulardan olan alerjik astım ve rinit gelişimi görülür. İnfantil dönemde başlangıç gösteren olguların \%80'ninde alerjik rinit gelişmektedir. ${ }^{1.3}$

\section{immunopatoloji:}

AD gelişiminde immunolojik yolaklarda Langerhans hücreleri (LH) ve antijen sunan diğer hücrelerden dentritik hücreler $(\mathrm{DH})$, miyeloid $\mathrm{DH}$, inflammatuvar $\mathrm{DH}$, plazmasitoid $\mathrm{DH}$ ve yanı sıra monosit, makrofaj, eozinofil, mast hücreleri, lenfositler, bazofiller, keratinositler görev alırlar. $\mathrm{LH}$ ve inflamatuvar DH myeloid DH grubundandır. Bunlardan özellikle FcER1 taşıyan inflamatuvar $D H^{\prime}$ ler $A D^{\prime}$ de inflame deride bulunurlar. ${ }^{1.3}$ $A D^{\prime}$ de inflamatuvar süreç bifaziktir, akut dönemde Th2 ağırlıklı olan inflamasyon kronik süreçte Th1 ağılıklı olarak devam eder. Regulatuvar T hücreleri (CD4+ CD25+, Treg) normalde hem Th1 hem de Th2 hücre gruplarının fonksiyonlarını düzenlemektedir. Treg selftoleransın devamı için gerekli hücreler olup eksikliği ya da fonksiyon bozukluğu otoimmün ya da alerjik hastalıkların gelişimi ile ilişkili bulunmuştur. ${ }^{10} A D^{\prime}$ de Th17 hücrelerinin azalmış oranının artmış eozinofil ve IgE seviyeleri ile birliktelik gösterdiği, bu nedenle de hastalık aktivitesiyle ilişkili olabileceği düşünülmektedir."

Başlıca LH ve makrofajlar hem akut dönemde hem de sayıca artmış olarak kronik dönemde ortamda bulunurlar. Diğer DH ile birlikte ortam- 
daki T hücrelerinin antijen ve süperantijenlere (irritan maddeler, otoantijenler, alerjenler, S. aureus gibi) karşı artmış reaktivitesine yol açarlar. Keratinositler de patogenezde rol almaktadır. Bu hücreler, GMKSF ve TNF- $\alpha$ eksprese ederler, bu yolla DH'lerin, monositlerin, T hücrelerinin, eozinofillerin aktivasyonunu sağlar, yaşam sürelerini uzatırlar. ${ }^{1}$ Timik stromal lenfopoietin (TSLP) keratinositlerden sentezlenir. Dermisteki DH'lerin aktivasyonunu, göçünü düzenler, DH'lerin proinflamatuvar sitokin sentezlemelerini ve nativ $T$ hücrelerinin Th2 yönünde farklılaşmasını kontrol eder. ${ }^{12,13}$

Patogenezi özetlemek gerekirse, epidermal LH alerjen ya da otoalerjeni yakaladıktan sonra antijen sunma işleminden geçirerek yüzeylerindeki MHC molekülleriyle T lenfositlere sunarlar. Bir grup LH ise o bölgeyi drene eden lenf nodlarında T hücrelerini uyarır. Monositlerden salgılanması uyarılan prostaglandin E2 ve IL 10, keratinositlerden salgılanan TSLP ile birlikte T hücrelerinin Th2 yönündeki differansiyasyonunu sağlar. Uyarılan CD4+ Th2 hücrelerinden bu aşamada IL-4, IL-5, IL-13 salgılar. IL-4 ve IL-13 B hücrelerinin Ig E sentezlemesini sağlar. IL-5 ise eozinofil ve bazofillerin diferansiyasyonu ile aktivasyonunu sağlar. CLA (kutanöz lenfosit antijen) ve CD40 ligand taşıyan Th2 hücreleri CCL-17, CCL-11 ve CCL-5 gibi kemokinler yardımıyla deriye gelerek endotel hücrelerin yüzeyindeki adezyon moleküllerinden olan E-selektin, P-selektin, vasküler hücre adezyon molekülü 1 ve interselüler adezyon molekülü 1 sentezini arttırarak inflamasyonun devamını sağlarlar. Eozinofiller ve mast hücreleri de ortamda erken dönemden itibaren bulunurlar. Mast hücrelerinin yüzeyindeki FceR1 uyarılması TNF- $\alpha$, IL4, IL-13 sentezine katkıda bulunur. Ortamdaki eozinofillerden salgılanmaya başlayan IL-12'de Th2 ağırlıklı akut inflamasyonun Th1 ağırlıklı kronik inflamasyona dönüşmesini destekler. Sonuç olarak akut lezyonlar kronikleştiğinde Th1 hücrelerin ortamdaki sayısı artmıştır ve ortamda IFN-Y sentezlenmektedir. Kronik süreçte seviyesini artan sitokinler IL$12, \mathrm{IL}-18$ ve IFN- $\gamma$ yanı sıra IL-5, GMKSF, IL-11, IL-17, TGF $-\beta 1^{\prime}{ }^{\prime}$ dir. ${ }^{1-3}$

\section{Nöromediatörler:}

Substance $P$, beyin kaynaklı büyüme hormonu gibi nöropeptitler ve nörotropinler T hücre fonksiyonları üzerine direk etki göstermeseler de Langerhans ve mast hücreleri üzerine olan etkileri ile hastalık patogenezinde rol alırlar. Bu maddelerin plazma ve serumdaki seviyelerinin hastalık şiddeti ile korelasyon göstermesi de patogenezdeki rollerini desteklemektedir. ${ }^{14}$

\section{Derinin bozulmuş bariyer fonksiyonu:}

Defektif filagrin varlığında anormal epidermal bariyer gelişmekte, yüksek moleküler ağırlığa sahip alerjenler, bakteri ve virüslerin epidermal geçisi kolaylaşmaktadır.' Bu durum, protein antijenlere karşı kutanöz sensitizasyonu arttırmakta AD patogenezinde rol alan Th2 dominant sistemik yanıtın gelişmesine, protein antijenlere karşı havayolu hiperreaktivitesine yol açmakta ve astım gelişimi için predispozisyon oluşturmaktadır. ${ }^{1.3}$ Ancak, filagrin mutasyonlarının fonksiyonel sonuçları ve yol açtıkları fenotipik özellikleri halen netlik kazanmamıştır. AD olgularında deri PH'sının arttığı ve bu artışın filagrin mutasyou taşıyan grupta anlamlı derecede yüksek olduğu gösterilmiş, bunun filagrin yıkım ürünleri ile ilişkili olduğu belirtilmiştir. ${ }^{15}$ Ancak, kesin olarak araştırmaların ortaya koyduğu önemli nokta, AD olgularında seramid yapısında ve profilinde sağlıklı populasyona göre değişikliklerin olduğu ve bunun da stratum korneumun su tutma kapasitesinin azalmasına, transepidermal su kaybının artmasına yol açtığıdır. ${ }^{16}$

\section{Mikrobiyal ajanlar:}

AD olgularının derisini S. aureus kolonize eder. Bunun en önemli nedeni; antimikrobiyal peptitlerden $\beta$ defensin (HBD-2 ve HBD-3) ile katelisidin
(hCAP18/LL-37) ekspresyonlarının azalması ve yanı sıra bozulmuş epidermal bariyerin varlığıdır. AD'de immunolojik olarak CD8+sitotoksik T hücrelerinin sayısı ve aktivitesi ile birlikte natural killer (NK) hücrelerinin de aktivitesi azalmaktadır. Gecikmiş tip hipersensitivite yanıtı azalmakta, ayrıca azalmış plazmositoid DH popülasyonu nedeniyle bu olgularda HSV, molluskum kontagiosum, HPV infeksiyonları gibi viral infeksiyonlar ile yüzeyel fungal infeksiyonlar daha sık gelişmektedir. ${ }^{1,3}$

Deriyi kolonize eden ya da infekte eden mikroorganizmaların protein, karbonhidrat ve glikolipid yapıdaki maddeleri Klas I ve Klas II MHC molekülleri yoluyla sunularak ya da süperantijenler gibi davranarak $A D$ lezyonlarını arttırabilmektedir. Poliklonal $T$ hücrelerinin büyük miktarlarda uyarılması ve süperantijenler CD4+CD25+ Treg'leri de inhibe ederler. ${ }^{1}$

\section{Klinik Bulgular:}

Hastalık infantil, çocukluk ve erişkin dönemde seyri ve klinik özellikleri ile birtakım farklılıklar göstermektedir. İnfantil dönemde akut inflamasyon ve eksudasyonla karakterize lezyonlar özellikle ekstensör ve fasiyal bölgelere yerleşim gösterir. Bebek bezi alanı ile yüzde perioral ve perinazal alanlar çoğunlukla korunmuştur. Lezyonların bu dağılımı bebeğin kaşıntısını sürtme yoluyla ekstensör bölgelerde daha rahat yaşaması ile ilişkili olarak gelişmektedir. Emekleme ile birlikte dizlerde etkilenir. Saçlı deride seboreik dermatit ile karışabilen sarı kurutlu lezyonlar görülebilir. Olguların \%20 ile 30'unda iki yaşın sonunda deri lezyonları geriler. Yaşla birlikte kronik inflamasyon ve likenifikasyon ön planda seyreder ve lezyonlar fleksural bölgelere yerleşme eğilimi gösterir. İki yaşından sonra antekubital, popliteal fossa, boyun bölgesi etkilenmeye başlar. Erişkin dönemde ise bazı olgularda yüz tutulumu özellikle de göz kapağı tutulumu belirgin iken bazı olgularda hastalık kronik el ekzeması ya da eritrodermi ile seyredebilmektedir. ${ }^{1.3}$

Hastalık bulguları akut, subakut ve kronik bir seyir gösterir. Akut dönemde yoğun kaşıntılı eritemli, ödemli papül ve plaklar, vezikül, sızıntı ve seröz kurutlanma görülür. Subakut dönemde eritemli papül ve plaklar, kabuklanma ve ekskoriyasyonlar görülür. Kronik AD kalınlaşmış, hiperkeratotik, pigmente, likenifiye plaklar ve prurigo nodülaris ile karakterizedir. Iyileşen lezyonlar yerlerinde postinflamatuvar hipo ya da hiperpigmentasyon bırakabilirler. Lezyonlar perifolliküler belirginlik gösteren yassı lezyonlar ile karakterize papüler ekzema olarak izlenebilir. ${ }^{1-3}$

AD seyrinde bazı protein yapıdaki maddelere karşı kontakt dermatit gelişebilmektedir. Bazı meyve (muz, kivi, ananas, limon), tahıl (arpa, buğday, çavdar), et, fındık, fıstık, baharat, hayvan kepeği, kıl, salyası, lateks bunların başında gelmektedir. Protein yapıdaki kontakt alerjenler standart yama testi serileri ile saptanamaz, bunlar için deri prick testleri kullanılabilir.

Kaşıntı; en önemli bulgudur. Akşama doğru, terleme ve yünlü kıyafetlerin givilmesiyle artış gösterir. Sürtme ya da kaşıma davranışı ile çizgisel ekskoriyasyonlar ile plaklarda likenifikasyon gelişir. Yoğun kaşıntı sonucu özellikle ekstremitelerde prurigo nodülaris gelişebilir.

Kserozis; hastalığa eşlik eden en sık bulgulardan biridir. Hastaların \%80-98'inde görülür. Kserozis, irritan maddelerin stratum korneumdan geçişini kolaylaştırır. Kaşıntıyı arttırır.

Keratozis pilaris: Kol ve bacakların lateral bölgelerinde folliküler hiperkeratinizasyon ile karakterizedir. Follikül çevresinde eritem belirgindir. Çocuklarda yüz bölgesinde birleşme eğilimi gösteren eritem görülür. ${ }^{1-3}$

\section{Laboratuvar:}

AD seyrinde olguların serum IgE seviyeleri yükselebilir, eozinofili gelişir. Minör tanı kriterlerindendir. Olguların \%20-30'unda serumda eozinofili ya da IgE yüksekliği olmayabilir. Deri testleri ve spesifik IgE hastalığı 
provoke eden faktörleri ortaya koyma açısından önemlidir. Ancak bu testlerin sonuçları provakasyon testleri ile doğrulanmalıdır. Atopi yama testi sensitivitesi düşük spesifik bir testtir, başlıca aeroalerjenlere yönelik olarak kullanılabilir. ${ }^{1}$

\section{Ayırıcı Tanı:}

Hastalığın ayırıcı tanısında infeksiyonlar, enfestasyonlar, metabolik, genetik, otoimmün çok sayıda hastalık yer alır. Hastanın yaşına, lezyonların klinik yerleşimine göre değişir. Bebeklik döneminde WiskottAldrich sendromu, hiperimmünglobülin $\mathrm{E}$ sendromu ekzematöz deri lezyonları ile seyreder. Erişkin dönemde kutanöz T hücreli lenfoma ve Sezary sendromu ayırıcı tanıda düşünülüp gerekirse farklı vücut alanlarından yapılacak çoklu deri biyopsileri ile ekarte edilmelidir.'

\section{Histopatolojik Bulgular:}

Akut ve kronik dönemde histopatolojik bulgular farklılıklar gösterir. Akut dönemde epidermiste spongiyoz, mikro veya makro vezikül formasyonu, lenfosit ekzositozu, dermiste perivasküler lenfositoz görülür. Erken dönemde dermal venüllerdeki endoteller genişlemiştir. Dermal alanda ise perivasküler yerleşimli CLA sentezleyen aktive T hücreleri artmıştır.'

Subakut dönemde spongiyoz gözlenirken vezikül formasyonu olmaz ve epidermis kalınlaşmıştır. Kronik lezyonlarda ise epidermiste kalınlaşma ile psoriasiform bir patern gözlenebilir. İnflamasyon ve spongiyoz hafif derecededir ya da hiç gözlenmez. Granüler tabaka değişkendir, sürtünmenin belirgin olduğu durumlarda epidermal tabaka kalınlaşır, numuler ekzema gibi psoriasiform lezyonlarda ise incedir. ${ }^{1-3}$

\section{Atopik Dermatit Komplikasyonları}

Atopik dermatit seyrinde infeksiyon, ödem, eritrodermi ve tedavi ilişkili komplikasyonlar gelişebilir.

Infeksiyon: AD olgularında S. aureus ilişkili kutanöz infeksiyonların görülme sıklığı artmıştır. S. aureus'un ekzotoksinleri süperantijen gibi davranarak mevcut hastalığı alevlendirici rol oynayabilir. Verrü, molluskum kontagiozum, herpes virüs infeksiyonları gibi viral infeksiyonlar ile Malassezia spp. ve Candida spp.'lere bağlı fungal infeksiyon görülme sıklığı da artmıştır. AD olgularında gelişen HSV infeksiyonlarından ekzema herpetikum özellikle çocuk hastalarda sistemik antiviral tedavi gerektirebilmektedir.

Ödem: Özellikle alt ekstremitelerde kronik inflamasyon ile ilişkili olarak gelişebilmektedir.

Atopik dermatit tedavisine bağlı komplikasyonlar: Topikal ve sistemik kortikosteroid kullanımı ile ilişkili olarak atrofi, ekimoz, telenjiektazi, yara iyileşmesinde gecikme, oküler katarakt, sitria gelişebilir. Topikal steroidlerin yüz bölgesine kullanımı rozasea, perioral dermatit gelişmesine yol açabilir. Sistemik steroid kullanımı ile ilişkili komplikasyonların başında ise iyatrojenik Cushing sendromu, hipertansiyon, hiperglisemi, osteoporoz gelişimi yer alır.

AD olgularında tedavide kullanılan topikallere karşı irritan ve alerjik kontakt reaksiyonlar gelişebilir. Topikal steroidlere karşı gelişen reaksiyonları tanımak oldukça güç olabilmektedir. Bunun için dilue topikal steroid preparatları ile yapılan yama testi sonuçlarının 10 gün gibi geç bir dönemde değerlendirilmesi önerilmektedir. ${ }^{1.3}$

\section{Tedavi}

Tedavi üç ana prensibe dayanır. Bunlardan bozulmuş epidermal bariyere yönelik olarak derinin nemlendirilmesi ilk ve en önemli adımdır. Mikrobiyal kolonizasyonun kontrolü, ve inflamasyonun önlenmesi ile baskılanması diğer önemli adımlardır. İnflamasyonun önlenmesi amacıyla irritan ve alerjik maddelerden kaçınılması gerekmektedir. İnflamasyonun supresyonu için topikal steroidler, topikal kalsinörin inhibitörleri, fototerapi, immunsupresif sistemik ajanlar tedavinin esaslarını oluşturmaktadır. ${ }^{1-3}$

\section{Primer Korunma:}

Primer korunmanın hamilelikte başlayabileceği belirtilmektedir. Hamilelikte korunmada diyetin etkinliği ile ilgili sonuçlar halen netlik kazanmamıştır. Diyette inek sütü, yumurta, ortamda ev tozu akarları maruziyetinin hamilelik ve emzirme döneminde kısıtlanmasına ilişkin sonuçlar çelişkilidir. Bebeklik döneminde anne sütünün koruyucu olabileceği yönünde yayınların varlığına karşın uzun süreli emzirme ile $A D$ sıklığının arttığı gibi çelişkili sonuçlar da vardır. AD gelişme riski yüksek olan bireylerde standart inek sütü formüllerinin beslenmede kullanımasına karşılık kısmi hidrolize edilmiş inek sütü mamalarının kullanımasının AD gelişmesini önlemede etkili olduğu ve hatta hafif ve orta şiddetli AD olgularında hastalık aktivitesini azalttığı randomize plasebo kontrollü bir çalışma ile de gösterilmiştir. ${ }^{17}$

Randomize plasebo kontrollü çalışmalar ile probiyotik alımının hamilelikte ve infantlarda AD görülme sıklığını 2-4 yaş arasında anlamlı derecede azalttığını ortaya konmuştur. Probiyotikler barsak florasını değiştirerek antijen emilimini azaltmakta ve atopik dermatitte azalan Th1 immün yanıtını desteklemektedir.

Atopik dermatitli bir olguda primer korunmada en önemli nokta alerjenlerden ve irritanlardan kaçınılmasıdır. Kimyasallar, alkalin sabunlar, ev tozu akarları bunların başında gelmektedir. Akarları ev ortamında azaltmak için akarisit, vakum gücü fazla, filtreli süpürgeler, goreteks malzeme kullanılabilir. ${ }^{1,3}$

\section{Destek tedavisi:}

Bozulmuş epidermal bariyerin desteklenmesi ve iyi bir hidrasyon önemlidir. Günlük 10-20 dakikalık ılık banyo sonrası ilk üç dakika içinde derinin nemlendirilmesi, derinin bariyer fonksiyonunu ve nem oranını arttırır. Yaş pansuman ya da banyo sonrası topikal steroidlerin kullanımının da etkili olduğu belirtilmektedir. Nemlendirme için yağ içinde su emülsiyonu tercih edilmelidir. Su oranı yüksek olan su içinde yağ emülsiyonları yanma batma hissine yol açar ve deriyi yeterince nemlendirmezler. Alfa ve beta hidroksi asitler veya üre içeren emülsiyonlar derinin nem tutma kapasitesini arttırırlar, ancak inflame deride yanma batma hissine yol açabilirler, bu nedenle öncelikle bir test alanına uygulanmaları önerilmektedir.' Bebek ve çocuklarda üre en fazla \%4 erişkinde ise en fazla \%10 oranında kullanılmalıdır. ${ }^{3}$ Bunun dışında \%20'lik gliserolün ${ }^{18}$ ve seramid içeren yağların derinin hidrasyonunu arttırdığı gösterilmiştir. ${ }^{19,20}$

AD olguların deri temizliğinde hafif, non alkalin özellikteki temizleyiciler önerilir. Köpük banyolarından ve kokulu banyo tuzlarından kaçınılmalıdır. Klorlu havuzlarda yüzülmesi, sıcak jakuzilere girilmesi deride irritasyonu arttırır. Saçlı deri bakımında katranlı şampuanlar banyolar, krem ve losyonlar antiinflamatuvar etkinliklerinden dolayı kaşıntıyı azaltsa da inflame deride irritasyona yol açabilirler.

AD olgularında kıyafet olarak yünlü ve sentetik kıyafetlerden kaçınılması ve pamukluların giyilmesi önerilmektedir. Gümüş içeren tekstil ürünlerinin S. aureus kolonizasyonunu azalttığı ve toksin üretimlerini baskıladığı, sonuçta AD olgularında SCORAD indeksini ve kaşıntı skorlarını anlamlı oranda azalttığı ortaya konmuştur. ${ }^{21}$

\section{Antimikrobiyal tedavi:}

Gram pozitif etkinliği olan topikal antibiyotikler ile sistemik olarak sefalosporinler, beta laktam -beta laktamaz inhibitör kombinasyonları tedavide kullanılabilir. Ancak bu ajanların profilaktik kullanımlarının yararı yoktur. Son yıllarda toplumdan kazanılmış metisilin rezistan S. aureus prevealansının artması nedeniyle bakteri kolonizasyonun azaltılması amacıyla dilue sodyum hipoklorit banyosu', \%2'lik triklosan ya da triklosan/klorheksidin kombinasyonunun $(\% 0,3 / \% 0,34)$ düşük konsantrasyonları antiseptik solüsyon olarak kullanılabilir. ${ }^{22} \mathrm{~S}$. aureus 
burun taşıyıcılığı saptanan olgularda mupirosin ya da fusidik asit tedavide kullanılabilir. ${ }^{23}$

\section{Farmakolojik Tedavi ve Fototerapi:}

Topikal olarak steroid içerem krem ve pomadlar, kalsinörin inhibitörleri kullanılır. Fototerapi, antimikrobiyal ajanlar, sistemik immunsupresif ajanlar, antihistaminikler hastalığın şiddetine göre ve hastanın tedaviye yanıtına göre seçilir.

\section{Topikal tedavi:}

AD tedavisinde topikal steroidler birinci basamak tedavi ajanlarıdır. Özellikle yaş pansuman sonrası ya da banyo sonrası kullanımları ilacın emilimini ve dolayısıyla etkinliğini arttırmakta, taşıyıcı bazın nemlendirici etkisine katkı sağlamaktadır. ${ }^{24}$ Kısmi fayda gösteren zayıf etkili steroidlerin uzun süreli kullanımı yerine, güçlü ve çok güçlü steroidlerin kısa sürede etkili kullanımları yan etkiler göz önünde bulundurularak dengelenmelidir. Steroidler kıvrım bölgelerinde ve yüz bölgesinde dikkatli kullanılmalıdır. Orta potent steroidler (triamsinolon asetonid gibi) likenifiye olmayan ince plakların tedavisinde geniş alanlara kullanılabilir. Streoidlerin uzun süreli kullanımlarında taşiflaksi gelişir, bu nedenle aktif dönemde günde iki defa kullanımları, hastalık alevlenmesinin önlenmesi amacıyla ise tedavinin haftada iki gün olarak idame ettirilmesi önerilmektedir. Likenifiye lezyonların varlığında öncelikle potent steroidler tercih edilmelidir. Oklüziv uygulamalar yapılabilir. ${ }^{1-3}$

Kalsinörin inhibitörleri topikal kortikosteroidlerin aksine, daha az yan etkiye sahiptirler. Kollagen sentezini inhibe etmedikleri için kutanöz atrofi yapmazlar. Topikal kortikosteroidlerin uzun süre kullanılamayacağı yüz derisi ve fleksural alanlar gibi hassas ve ince deri bölgelerinin tedavisinde kullanılabilirler. Takrolimus orta ve şiddetli $A D$, pimekrolimus ise hafif ve orta şiddette AD varlığında tercih edilmelidir. Bu ajanlar T hücre aktivasyonunu ve özellikle inflamatuvar $\mathrm{DH}^{\prime}$ leri önlerler. Topikal steroidler ile kontrol altına alınan atağın idame tedavisinde uygulanabilirler. Sıklıkla iyi tolere edilirler, uygulama alanında yanmabatma hissine yol açabilirler. Emilimleri geniş alanlarda bile düşük miktarlarda saptanmıştır. Sistemik immunsupresyona yol açmazlar. FDA 2006 yılında hayvan deneylerinde insandaki seviyenin 30-50 katı miktardaki sistemik kullanımında lenfoma gelişimi bildirmesi üzerine ilaca black box konulmuştur. Bu açıdan ilacın takibi devam etmektedir., ${ }^{1,25}$

\section{Fototerapi:}

Fototerapi AD lezyonlarında temel olarak T hücrelerinin apoptozisini indukleyerek ve LH sayısını azaltarak etki göstermektedir. ${ }^{26}$ Çocuk hastalarda fototerapi kararı uzun dönem yan etkiler göz önünde bulundurularak verilmelidir. UVB (280-320 nm), UVA (320-400 nm), uzun dalga UVA1 (340-400 nm), darbant UVB (311-313 nm), kombine UVA ve UVB ve psoralen-UVA (PUVA), banyo PUVA, doğal gün ışığı $A D$ tedavisinde faydalıdır. Güneş yanığı, foto yaşlanma ve uzun süreli tedaviler sonunda artmış kutanöz malinite gelişimi önemli yan etkileridir. UVA1 tedavisi ve özellikle de orta doz UVA1, konvansiyonel UVA ve UVB tedavilerine göre daha etkili bulunmuştur. ${ }^{26-28}$ Darbant UVB tedavisi geniş bant UVB tedavisine daha etkili ve yanık gibi yan etkileri açısından daha güvenlidir. ${ }^{26}$

\section{Sistemik steroidler:}

Şiddetli olgularda atakların akut kontrolünde sistemik steroidler kısa süreli kullanılabilir. Ancak tedavi kesilmesini takiben hastalıkta rebound görülebilir. Sistemik yan etkilerinden dolayı uzun süreli kullanımından kaçınılmalıdır.

\section{Siklosporin:}

Oral siklosporin 2,5-5 mg/kg/gün dozlarında AD tedavisinde etkilidir. Ancak uzun süreli kullanımda hipertansiyon, lenfoma gelişimi ve nefrotoksisitesi güvenle kullanımını sınırlamaktadır.,29

\section{Sistemik Diğer Tedaviler:}

Metotreksat 2,5-25 mg haftada değişen dozlarda, azatiyopürin tiyopürin metil transferaz aktivitesine göre 0,5-1 mg/ $\mathrm{kg} /$ gün ile 2-3,5 $\mathrm{mg} / \mathrm{kg} / \mathrm{gün}$ arasında değişen dozlarda, mikofenolat mofetil ya da mikofenolik asit sodyum 25-50 mg/kg/gün dozunda çocuk ve erişkinlerde kullanılabilir. ${ }^{1-3,30}$ Bu tedaviler yanı sıra IFN- $\gamma$, omalizumab, ekstrakorporeal fotokemoterapi az ayıda dirençli olguda etkili bir şekilde kullanılmıştır. Omalizumab humanize anti - Ig E antikorudur. ${ }^{1-3,30}$ Ig E'nin reseptöre bağlanmasını bloke eder. Şiddetli seyreden ve konvansiyonel tedavilere dirençli AD olgularında etkili olabileceği bildirilmiştir. ${ }^{31}$

\section{Antihistaminikler:}

Patogenezde histamin direk bir rol oynamadığı için antihistaminiklerin etkinliği kısıtlıdır. Ancak, kaşıntı döngüsünü kırmak adına hidroksizin, difenhidramin, doksepin gibi sedatif etkili antihistaminikler özellikle gece yatmadan bir saat önce hastalara verilebilir. ${ }^{1-3}$

Subkutan ya da sublingual immunoterapinin etkinliği halen netlik kazanmamıştır. Bu konudaki çalışmalar devam etmektedir. Alternatif tedaviler arasında yer alan Çin herbal tedavileri, hipnoterapi, biyofeedback, masaj terapisi, diyet lipid tedavisi gibi tedavilerin etkinlikleri ise tartışmalıdır. Yakın gelecekte ise deneysel tedavilerden NFKB'nin topikal kullanımı olası gözükmektedir. ${ }^{1-3}$

\section{Kaynaklar}

1. Kang K, Polster AM, Nedorost ST, Stevens SR, Cooper KD: Atopic dermatitis. Dermatology. Ed. Bolognia JL, Jorizzo JL, Rapini RP. Spain, Mosby 2008; 181-95.

2. Darsow U, Wollenberg A, Simon D, Taïeb A, Werfel T, Oranje A, et al: European Task Force on Atopic Dermatitis/EADV Eczema Task Force. ETFAD/EADV eczema task force 2009 position paper on diagnosis and treatment of atopic dermatitis. J Eur Acad Dermatol Venereol 2010; 24:317-28.

3. Bieber T: Atopic dermatitis. Ann Dermatol 2010; 22:125-37.

4. Kalyoncu AF, Cöplü L, Selçuk ZT, Emri AS, Kolaçan B, Kocabaş A, et al: Survey of the allergic status of patients with bronchial asthma in Turkey: a multicenter study. Allergy 1995; 50:451-5.

5. Civelek E, Sahiner UM, Yüksel H, Boz AB, Orhan F, Uner A: Prevalence, burden, and risk factors of atopic eczema in schoolchildren aged 10-11 years: a national multicenter study. J Investig Allergol Clin Immunol 2011; 21:270-7.

6. Slattery MJ, Essex MJ, Paletz EM, Vanness ER, Infante M, Rogers GM, Gern JE: Depression, anxiety, and dermatologic quality of life in adolescents with atopic dermatitis. J Allergy Clin Immunol 2011; 128:668-71.

7. Morar N, Cookson WO, Harper Jl, Moffatt MF: Filaggrin mutations in childrenwith severe atopic dermatitis. J Invest Dermatol 2007; 127:1667-72.

8. Palmer CN, Irvine AD, Terron-Kwiatkowski A, Zhao Y, Liao H, Lee SP, et al: Common loss-of-function variants of the epidermal barrier protein filaggrin are a major predisposing factor for atopic dermatitis. Nat Genet 2006; 38:441-6.

9. O'Regan GM, Irvine AD: The role of filaggrin in the atopic diathesis. Clin Exp Allergy 2010; 40:965-72.

10. Honda T, Miyachi Y, Kabashima K: Regulatory T cells in cutaneous immune responses. J Dermatol Sci 2011; 63:75-82.

11. Hayashida S, Uchi $H$, Moroi $Y$, Furue M: Decrease in circulating Th17 cellscorrelates with increased levels of CCL17, IgE and eosinophils in atopic dermatitis. J Dermatol Sci. 2011; 6:180-6.

12. Soumelis V, Reche PA, Kanzler H, Yuan W, Edward G, Homey B, et al: Human epithelial cells trigger dendritic cell mediated allergic inflammation by producing TSLP. Nat Immunol 2002; 3:673-680.

13. Liu YJ. Thymic stromal lymphopoietin: master switch for allergic inflammation. J Exp Med 2006; 203:269-273.

14. Toyoda M, Nakamura M, Makino T, Hino T, Kagoura M, Morohashi M: Nerve growth factor and substance $P$ are useful plasma markers of disease activity in atopic dermatitis. Br J Dermatol 2002; 147:71-79.

15. Jungersted JM, Scheer $H$, Mempel M, Baurecht H, Cifuentes L, Høgh JK, et al: Stratum corneum lipids, skin barrier function and filaggrin mutations in patients with atopic eczema. Allergy 2010; 65:911-8.

16. Ishikawa J, Narita H, Kondo N, Hotta M, Takagi Y, Masukawa $Y$, et al: Changes in the ceramide profile of atopic dermatitis patients. J Invest Dermatol 2010; 130:2511-4. 
17. Jin YY, Cao RM, Chen J, Kaku Y, Wu J, Cheng Y, et al: Partially hydrolyzed cow's milk formula has a therapeutic effect on the infants with mild to moderate atopic dermatitis: a randomized, double-blind study. Pediatr Allergy Immunol 2011; 22:688-94.

18. Breternitz $M$, Kowatzki $D$, Langenauer $M$, Elsner $P$, Fluhr JW. Placebocontrolled, double-blind, randomized, prospective study of a glycerol-based emollient on eczematous skin in atopic dermatitis: biophysical and clinical evaluation. Skin Pharmacol Physiol 2008; 21:39-45.

19. Chamlin SL, Kao J, Frieden IJ, Sheu MY, Fowler AJ, Fluhr JW, et al: Ceramide-dominant barrier repair lipids alleviate childhood atopic dermatitis: changes in barrier function provide a sensitive indicator of disease activity. Am Acad Dermatol 2002; 47:198-208.

20. Na JI, Hwang JS, Park HJ, Kim DH, Park WS, Youn SW, et al: A new moisturizer containing physiologic lipid granules alleviates atopic dermatitis. J Dermatolog Treat 2010; 21:23-7.

21. Juenger M, Ladwig A, Staecker S, Arnold A, Kramer A, Daeschlein G, et al: Efficacy and safety of silver textile in the treatment of atopic dermatitis (AD). Curr Med Res Opin 2006; 22:739-50.

22. Wohlrab J, Jost G, Abeck D: Antiseptic efficacy of a lowdosed topical triclosan/chlorhexidine combination therapy in atopic dermatitis. Skin Pharmacol Physiol 2007; 20:71-6.

23. Breuer K, HAussler S, Kapp A, Werfel T: Staphylococcus aureus: colonizing features and influence of an antibacterial treatment in adults with atopic dermatitis. Br J Dermatol 2002; 147:55-61.
24. Dabade TS, Davis DM, Wetter DA, Hand JL, McEvoy MT, Pittelkow MR, et al: Wet dressing therapy in conjunction with topical corticosteroids is effective for rapid control of severe pediatric atopic dermatitis: Experience with 218 patients over 30 years at Mayo Clinic. J Am Acad Dermatol 2011 Oct 4. [Epub ahead of print]

25. Czarnecka-Operacz M, Jenerowicz D: Topical calcineurin inhibitors in the treatment of atopic dermatitis - an update on safety issues. J Dtsch Dermatol Ges 2011 Oct 6. [Epub ahead of print]

26. Onsun N: Atopik Dermatitte Foto(kemo)terapi. Türkderm 2010; 44:112-4.

27. Dawe RS: Ultraviolet A1 phototherapy. Br J Dermatol 2003; 148:626-37.

28. Tzaneva S, Seeber A, Schwaiger M, Honigsmann H, Tanew A: High-dose versus medium-dose UVA1 phototherapy for patients with severe generalized atopic dermatitis. J Am Acad Dermatol 2001; 45:503-7.

29. Hijnen DJ, ten Berge O, Timmer-de Mik L, Bruijnzeel- Koomen CA, de Bruin-Weller MS: Efficacy and safety of long-term treatment with cyclosporin A for atopic dermatitis. J Eur Acad Dermatol Venereol 2007; 21:85-9.

30. Waxweiler WT, Agans R, Morrell DS: Systemic Treatment of Pediatric Atopic Dermatitis with Azathioprine and Mycophenolate Mofetil. Pediatr Dermatol 2011 Oct 4. [Epub ahead of print] .

31. Ramírez del Pozo ME, Contreras Contreras E, López Tiro J, Gómez Vera J: Omalizumab (an anti-lgE antibody) in the treatment of severe atopic eczema. J Investig Allergol Clin Immunol 2011; 21:416-7. 